\title{
Aedes aegypti Resistant Against 0.02 ppm Temephos in Eight Districts/Municipalities in South Kalimantan Province
}

\author{
Dicky Andiarsa $^{1}$, Nita Rahayu ${ }^{1}$, Gusti Meliyanie ${ }^{1}$ \\ (andiarsa@gmail.com, nitarahayu79@gmail.com, gmeliyanie@gmail.com) \\ ${ }^{1}$ Balai Penelitian dan Pengembangan Kesehatan Tanah Bumbu, Kemenkes RI. \\ (Tanah Bumbu National Agency of Health Research and Development)
}

\begin{abstract}
Dengue Haemorrhagic Fever (DHF) is still a health problem in South Kalimantan. Series of outbreak of dengue cases covers almost all over districts/municipalities in the Province of South Kalimantan. This study carried out the susceptibility test of Aedes aegypti larvae against the larvacide temephos in eight districts/municipalities in South Kalimantan Province. Larvae Ae.aegypti taken in three areas of the health center with the most endemic for dengue, then reared in the Tanah Bumbu National Agency of Health Research and Development laboratory to the third progeny. The F-3 progeny larvae were exposed to temephos solution with concentrations $0.02 \mathrm{ppm}$ for one hour and the larval mortality were counted every hour. The results showed mortality of larvae with 0.02 ppm concentrations of temephos below $80 \%$ and defined as resistant. Surveillance regarding this susceptibility should be continued for a wider area as the initial control measures for spreading of larval resistance against temephos.
\end{abstract}

Keywords: Dengue haemorrhagic fever, resistance, Aedes sp., temephos

\section{Introduction}

Dengue Hemorrhagic Fever (DHF) is a serious public health problem in Indonesia. DHF is a viral disease that is transmitted through Aedes aegypti mosquitoes [1]. This mosquito plays an important role in the transmission of DHF, however several studies have reported that Aedes albopictus also has the potential to spread the disease [2], [3].

DHF is endemic in almost all areas of Indonesia with a prevalence that varies from low to high. Geographical distribution of mosquito vectors and dengue viruses triggered the emergence of dengue fever and dengue fever epidemics in the last twenty-five years, thus developing hyper endemicity in several regions in tropical countries including Indonesia [4]. During the last few decades DHF has increasingly severe clinical consequences for patients and often causes outbreak in most areas of Indonesia. The increase in dengue cases from the 
first time it appeared in Indonesia in 1968 to 2015 is quite wary of that is from 58 cases to 126,675 thousand cases [5].

Most DHF control still uses chemical materials to control the Aedes aegypti mosquito population. The Aedes larvae control in Indonesia still uses organophosphate larvacide namely Temephos, besides managing the program; they are still trying to move the Mosquito Nest Eradication (PSN) program by closing, draining, burying (3M) plus slogans. This has not yet reduced the use of chemical insecticides at the household level, so program managers continue to advise the community to use larvicide temephos as an effort to control mosquito larvae, especially in areas where residents prefer to store water for household supplies [6].

Temephos has been used for a long time and is still routinely used by the Health Service as one of the control efforts, especially if a case occurs in the area. Several studies in Indonesia have mentioned that resistance has occurred in temephos against Aedes spp [7]-[9]. However, the results of resistance and mortality from Aedes due to Temephos were different in each region. This has become an important background for vector control efforts to reconduct an assessment of the use of these temephos in the community. Regarding resistance, is it still an early indication that mosquitoes are beginning to become resistant due to errors in use or whether there has been a genetic mutation from mosquitoes that has spread and become resistant to these temephos, which needs to be further investigated? This study aims to provide additional references about the status of Aedes aegypti susceptibility to temephos, especially in the South Kalimantan region.

\section{Method}

This research was part of the Aedes aegypti Vulnerability Status Mapping study on Insecticides in Indonesia in 2015[10] and Mapping the status of Aedes aegypti's vulnerability to insecticides in South Kalimantan in 2016 [11] and obtained Research Ethics approval (exempted) by the National Health Ethics Commission, Health Research Agency No. LB 02.01/52/KE 105/2015 and LB 02.01/52/KE. 335/2016. This research was conducted in eight districts/cities in South Kalimantan Province. Each district was selected 3 sub-districts that have high endemicity of DHF and each sub-district was selected RW / village with high DHF cases in the region and 100 houses were taken randomly.

This research was in the form of larvae survey at each selected house. Every house visited was observed at a household water reservoir after the owner gave his agreement and signed the Informed Consent. The larvae found were taken and put in a place that has been filled with water so that the larvae taken remain alive. Maximum larvae were taken from 40 animals in each house and carried out maintenance in the field to adulthood and lay eggs. The collected eggs are taken to the Tanah Bumbu Research and Development Center Laboratory for re-breeding up to the 3rd offspring.

The susceptibility test on larvae to Temephos was carried out on third instar larvae. Vulnerability testing was done based on the Elliot method [12]. The number of larvae needed was 25 larvae with 4 replications and 1 control, so that the total number of larvae was 125 for 
each district/city. The tested temephos concentration was $0.02 \mathrm{ppm}$ in distilled water, while for control used aquades. To get temephos with concentration, dilution of stock solution using equation:

\section{$\mathrm{C} 1 \mathrm{~V} 1=\mathrm{C} 2 \mathrm{~V} 2$}

$\mathrm{C} 1$ = solution concentration $(\mathrm{ppm})$ before dilution

$\mathrm{V} 1=$ solution volume $(\mathrm{ml})$ before dilution

$\mathrm{C} 2=$ solution concentration $(\mathrm{ppm})$ after dilution

$\mathrm{V} 2=$ solution volume $(\mathrm{ml})$ after dilution

25 larvae were put into a glass/container which contained temephos with a concentration of $0.02 \mathrm{ppm}$. Then the larvae were left in contact with the insecticidal solution of temephos for one hour. The larvae were transferred into the filter after one hour and rinsed in a rinse container containing $250 \mathrm{ml}$ of distilled water. For each treatment the tested insecticide concentration was used one filter. The larvae were stored in a storage container containing $250 \mathrm{ml}$ of aquadest for 24 hours, and fed. Observations were made at 0,1 , and 24 hours. The number of larvae that fainted died, and the number of larvae that were still alive were counted and recorded. In this test if larval mortality is $>10 \%$ in control, then it is considered a failure and must be repeated. If it is less than $10 \%$, then the correction factor of the ABBOT formula was used [13] as follows:

Abbot formula: $\frac{A-B}{(100-B)} \times 100 \%$

A: Larval test death percentage

B: Larval control death percentage

Temperature measurements are recorded during the experiment. As a guide to interpreting WHO bioassay test results are death> 98\% indicate vulnerable species, 80-98\% mortality indicates tolerant species, and death $<80 \%$ indicates resistant species.

\section{Result}

The results shown in table 1 are that the Ae. Aegypti larvae in eight districts/cities in South Kalimantan Province were declared resistant to Temephos larvicides. The area with the highest larval mortality is Balangan Regency (52\%) while for the region with the lowest larval density is Banjarmasin City (12\%). The opposite is shown by Banjarmasin City which has the highest House index (64.6\%) of all regencies / cities examined. 
Table 1. Mortality of Aedes aegyti larvae to Temephos $0.02 \mathrm{ppm}$ based on district/city

\begin{tabular}{lcc}
\multicolumn{1}{c}{ District/cities } & $\begin{array}{c}\text { Mortality } \\
(\%)\end{array}$ & House Index (\%) \\
\hline Banjarmasin & 12 & 64,6 \\
Banjar & 15,9 (Abbot correction) & 50,3 \\
Balangan & 52 & 60 \\
Tabalong & 23 & 55 \\
Tapin & 31 & 37 \\
HSS & 46 & 36,33 \\
HST & 22,4 (Abbot Correction) & 37,33 \\
HSU & 19 & 45,67
\end{tabular}

\section{Discussion}

The 3rd generation larvae of mosquitoes collected in eight regencies/cities in South Kalimantan Province show that all have Temephos organophosphate larval status. Recommendations from the WHO state that a dose of Temephos $0.02 \mathrm{mg} / \mathrm{L}$ can normally kill all Aedes larvae from the field [12]. Circumstances that cause mosquito larvae partially or completely become more resistant to larvicides indicate resistance has occurred [14].

In general, there has been a tendency towards Ae. Aegypti larvae has been resistant to this Temephos in all districts examined. Themephos has been widely used in all regions in South Kalimantan. These results illustrate the development of resistance in larvae in selected areas. Table 1 show that the percentage of larval deaths varied in each district/city from Banjarmasin City which had the lowest mortality (12\%) to Balangan District with the highest larval mortality (52\%). This variation illustrates the potential for resistance which is not the same and is consistent, however the entire district examined can be declared to have occurred resistance. This is still local in nature, so further examination in other wider areas in South Kalimantan with varying dosages of the examination will provide more comprehensive information on the status of resistance of Ae.aegypti larvae to Temephos.

Aedes resistance to temephos was also reported to be able to trigger cross resistance to other organophosphate insecticides such as malathion and fenthion [15]. This is related to the increased activity of esterase in mosquitoes that are resistant to chlorpyrifos and temephos [15], [16]. The use of temephos and malathion together for at least four decades has been used in Indonesia. This long exposure leads to adaptation from mosquitoes and even becomes adaptive to other insecticides that have the same receptor target, including insecticides produced for households. Research in East Kotawaringin states that the use of household 
insecticides that have not been rotated for a long time is strongly correlated with the presence of larvae in the household [6].

Temephos is claimed to be non-toxic to both plants and animals and humans. This triggers the emergence of ignorance of use in the community both in terms of dosage and duration of use [14]. Temephos dosage forms in the community are small slow release granules (low solubility) and allow them to be used in the long run making it easier for the community to use them. Constraints that can arise from these use patterns will trigger selection of resistant to larvae exposed to low doses [14], [17]. This can occur in conditions when Aedes eggs have just hatched and coincided with a container that has just been refilled with water, so the levels of temephos in the container have not yet reached the optimal dose. This is consistent with the results of observations at the time of larval collection in households found larvae that are still alive in containers that according to respondents already contain abate (temephos) (unpublished data). The same results were found in research in Thailand [14].

Temephos has also been used as larvicide for a very long time, since the recommendation of WHO for controlling mosquito larvae in 1981 [12]. Mosquitoes are able to adapt to exposure to the same insecticide and are used for a very long time [7]. The target of receptors on insecticides may differ depending on the type of insecticide, but the notion of the role of detoxification enzymes in mosquitoes is very important for its ability to withstand insecticide exposure [18]. Evidence of Aedes mosquitoes has the potential to develop resistance to temephos also reported by Paeporn et al in his research in Thailand [19].

The weakness of this study is the use of just one concentration for this vulnerability test. This results in a limited concentration range that can be used as a resistant status and it is not known that the range of doses can still provide a knock down effect on larvae. In a study in Colombia using a dose of $1 \mathrm{ppm}$ for each container inside and outside the house and this study states that Aedes larvae from the Cucuta region, Colombia is able to survive up to $15 \mathrm{x}$ the standard dose used [20]. A study in Surabaya stated that the dosage of $1 \mathrm{mg} / \mathrm{L}$ temephos was still effective in the field conditions [21]. This can be used as a comparison of the efficacy travel conditions of a larvicide used in several regions. In this study produced an average mortality rate of $27.66 \%$ which means that temephos had a low killing power against Aedes larvae, but when compared with the effect of larvicide temephos that occur in Colombia was still lower. It can be concluded that resistance in the South Kalimantan region was still in the initial stages of resistance. It can be suggested that routine surveillance related to efficacy testing and susceptibility testing for larvicide temephos carried out over a wider area can provide early detection of potential larvicidal resistance such as this and effective control strategies can be carried out before an increase in resistant larvae with the distribution of wider areas [20]. 


\section{Conclusion}

The results showed that the mortality of larvae with temephos $0.02 \mathrm{ppm}$ was below $80 \%$ and based on the provisions of the WHO was determined as resistant. Surveillance for susceptibility testing can be continued over a wider area as an initial control effort in determining the extent of the distribution of larvae that are resistant to temephos.

\section{References}

[1] M. E. Beatty et al., "Best practices in dengue surveillance: A report from the asiapacific and americas dengue prevention boards," PLoS Negl. Trop. Dis., vol. 4, no. 11, p. e890, 2010, doi: 10.1371/journal.pntd.0000890.

[2] M. Sarwar, "Insect borne diseases transmitted by some important vectors of class insecta hurtling public health," Int. J. Bioinforma. Biomed. Eng., vol. 1, no. 3, pp. 311-317, 2015.

[3] A. P. G. Almeida et al., "Potential mosquito vectors of arboviruses in Portugal: species, distribution, abundance and West Nile infection.," Trans. R. Soc. Trop. Med. Hyg., vol. 102, no. 8, pp. 823-32, 2008, doi: 10.1016/j.trstmh.2008.03.011.

[4] M. R. Karyanti and S. R. Hadinegoro, "Perubahan Epidemiologi Demam Berdarah Dengue Di Indonesia," Sari Pediatr., vol. 10, no. 6, p. 424, 2016, doi: 10.14238/sp10.6.2009.424-32.

[5] L. Indriyati et al., “Aplikasi IJEN ( Infeksi Jamur Entomopatogen pada Nyamuk ) : Jamur Metarhizium anisopliae pada Nyamuk Aedes aegypti Aplication of Entomopathogen Fungi Infection to Mosquito : Metarhizium anisopliae to Aedes aegypti," J. Vektor Penyakit, vol. 13, no. 1, pp. 33-48, 2019.

[6] G. Meliyanie, R. I. Wahyudi, and D. Andiarsa, "The impact of insecticides use in the household to the presence of larvae / pupae of aedes aegypti in East Kotawaringin, Central Kalimantan," J. Heal. Epidemology Commun. Dis., vol. 2, no. 1, pp. 14-18, 2017, doi: 10.22435/jhecds.v2i1.5934.14-18.

[7] H. Prasetyowati, J. Hendri, and T. Wahono, "Status Resistensi Aedes aegypti (Linn.) terhadap Organofosfat di Tiga Kotamadya DKI Jakarta," Balaba J. Litbang Pengendali. Penyakit Bersumber Binatang Banjarnegara, vol. 12, no. 1, pp. 23-30, 2016, doi: 10.22435/blb.v12i1.4454.23-30.

[8] H. Fuadzy, D. N. Hodijah, A. Jajang, and M. Widawati, "Kerentanan Larva Aedes Aegypti Terhadap Temefos Di Tiga Kelurahan Endemis Demam Berdarah Dengue Kota Sukabumi,” Bul. Penelit. Kesehat., vol. 43, no. 1, pp. 41-46, 2015, doi: 10.22435/bpk.v43i1mar.3967.

[9] Istiana, F. Heriyani, and Isnaini, "Larva Aedes aegypti sudah toleran terhadap Temephos di Kelurahan Sekumpul - Martapura Kabupaten Banjar Kalimantan Selatan," J. Buski, vol. 4, no. 2, pp. 66-72, 2012.

[10] Balitbangkes, "Pemetaan Pemetaan Status Kerentanan Aedes aegypti terhadap Insektisida di Indonesia," 2015.

[11] H. Nuhung et al., "Pemetaan Status Kerentanan Aedes aegypti terhadap Insektisida di Indonesia (Tahap 2)," 2016.

[12] WHO, "Instruction for determining the susceptibility or resistance of morquito larvae to insecticide." p. 8, 1981.

[13] D. Perwitasari, D. A. Musadad, H. S. P. Manalu, and A. Munif, "Pengaruh Beberapa 
Dosis Bacillus Thuringiensis Var Israelensis Serotype H14 Terhadap Larva Aedes Aegypti Di Kalimantan Barat," J. Ekol. Kesehat., vol. 14, no. 3, pp. 229-237, 2017, doi: 10.22435/jek.v14i3.4693.229-237.

[14] N. Jirakanjanakit, S. Saengtharatip, P. Rongnoparut, S. Duchon, C. Bellec, and S. Yoksan, "Trend of Temephos Resistance in Aedes (Stegomyia) Mosquitoes in Thailand During 2003-2005," Environ. Entomol., vol. 36, no. 3, pp. 506-511, 2007, doi: 10.1603/0046-225x(2007)36[506:totria]2.0.co;2.

[15] M. M. Rodriguez, J. Bisset, M. Ruiz, and A. Soca, "Cross-Resistance to Pyrethroid and Organophosphorus Insecticides Induced by Selection with Temephos in Aedes aegypti (Diptera: Culicidae) from Cuba," J. Med. Entomol., vol. 39, no. 6, pp. 882888, 2002.

[16] G. P. Georghiou, M. Wirth, H. Tran, F. Saume, and A. B. Knudsen, "Potential for Organophosphate Resistance in Aedes aegypti (Diptera: Culicidae) in the Caribbean Area and Neighboring Countries," J. Med. Entomol., vol. 24, no. 3, pp. 290-294, 1987, doi: 10.1093/jmedent/24.3.290.

[17] I. A. Braga, J. B. P. Lima, S. Da Silva Soares, and D. Valle, “Aedes aegypti resistance to temephos during 2001 in several municipalities in the states of Rio de Janeiro, Sergipe, and Alagoas, Brazil," Mem. Inst. Oswaldo Cruz, vol. 99, no. 2, pp. 199-203, 2004, doi: 10.1590/S0074-02762004000200015.

[18] E. P. Lima et al., "Insecticide resistance in Aedes aegypti populations from Cearáe, Brazil," Parasites and Vectors, vol. 4, no. 1, pp. 1-12, 2011, doi: 10.1186/1756-33054-5.

[19] P. Paeporn et al., "S Outheast a Sian J T Rop M Ed P Ublic H Ealth Temephos Resistance in Two Forms of Aedes Aegypti and Its Significance for the Resistance," Southeast Asian J. Trop. Med. Public Heal., vol. 34, no. 4, 2003.

[20] N. Grisales, R. Poupardin, S. Gomez, I. Fonseca-Gonzalez, H. Ranson, and A. Lenhart, "Temephos Resistance in Aedes aegypti in Colombia Compromises Dengue Vector Control," PLoS Negl. Trop. Dis., vol. 7, no. 9, 2013, doi: 10.1371/journal.pntd.0002438.

[21] K. C. Mulyatno, A. Yamanaka, Ngadino, and E. Konishi, "Resistance of Aedes aegypti (L.) larvae to temephos in Surabaya, Indonesia," Southeast Asian J. Trop. Med. Public Health, vol. 43, no. 1, pp. 29-33, 2012. 